\title{
A Cyclic Voltammetric Study of the Redox Reaction of Cu(II) in Presence of Ascorbic Acid in Different pH Media
}

\author{
Farhana Haque, M. S. Rahman, Etmina Ahmed, P. K. Bakshi and A. A. Shaikh* \\ Department of Chemistry, Dhaka University, Dhaka-1000, Bangladesh
}

(Received: 21 June 2012; Accepted: 26 January 2013)

\begin{abstract}
The electrochemical redox behavior of $\mathrm{Cu}(\mathrm{II})$, and $\mathrm{Cu}(\mathrm{II})$ in presence of ascorbic acid has been investigated at glassy carbon electrode (GCE) in aqueous phosphate buffer solution (PBS) at various $\mathrm{pH}$. In the studied $\mathrm{pH}$ range the voltammogram consists of a cathodic and an anodic peak. $\mathrm{Cu}$ (II) follows one step two-electron transfer electrochemical redox reaction. The intensities of both cathodic and anodic peak current increase with increasing scan rate that are consistent with Randles-Sevcik equation. The linear behavior of peak current with the square root of scan rate indicates that the electrochemical processes are diffusion controlled. In presence of ascorbic acid both of the cathodic and anodic peak current of $\mathrm{Cu}$ (II) is reduced and peak positions are shifted compared to those of $\mathrm{Cu}$ (II) alone. These observation suggest that $\mathrm{Cu}(\mathrm{II})$ undergoes a strong interaction with ascorbic acid in the studied medium.
\end{abstract}

Keywords: Cyclic voltammetry, Ascorbic acid, Phosphate buffer, Quasi-reversible.

\section{Introduction}

Copper (II) is one of the biologically important chemical species that functions as a co-factor in metalloenzymes and metalloproteins ${ }^{1}$. It is also regarded as an essential component of different organs such as blood, bones, teeth, nerves, etc. Its imbalance may result anemia, Wilson disease etc., and a number of other diseases in animals ${ }^{2}$. Its redox behavior may play a vital role to maintain its biological activities in association with different biomolecules especially with electron donor atoms at different $\mathrm{pH}$.

Ascorbic acid is a sugar acid with antioxidant properties which is commonly known as vitamin C. It is generally found in all plants, animals and single-cell organisms ${ }^{3}$. Reptiles and older orders of birds make ascorbic acid in their kidneys. Recent orders of birds and most mammals make ascorbic acid in their liver where the enzyme Lgulonolactone oxidase is required to convert glucose to ascorbic acid $^{4}$. Fat-soluble esters of ascorbic acid with longchain fatty acids can be used as food antioxidants.

Electrochemical redox reaction of $\mathrm{Cu}$ (II) in different supporting electrolytes media in the acidic $\mathrm{pH}$ range $\mathrm{e}^{5-10}$ and basic medium ${ }^{11,12}$ has been investigated because of its application in electrolysis, microelectronics, electroplating, sensors, batteries and biochemical catalytic systems ${ }^{13}$. The mechanism and kinetic behavior of the reduction of aquo$\mathrm{Cu}(\mathrm{II})$ have been investigated using a number of electrochemical techniques, such as dc polarography ${ }^{6,10,14}$, ac polarography ${ }^{6-17}$, hydrodynamic voltammetry ${ }^{18-20}$, chronoamperometry at constant potential ${ }^{8,21}$, and coulometry $^{22,23}$. Cyclic voltammetric study of $\mathrm{Cu}$ (II) in presence of various ligands have also been investigated and reported in details ${ }^{24-26}$. The present study reports the electrochemical redox behavior of $\mathrm{Cu}(\mathrm{II})$, and its interaction with ascorbic acid in aqueous phosphate buffer solution.

\section{Experimental}

Materials

Analar grade copper chloride $\left(\mathrm{CuCl}_{2} \cdot 2 \mathrm{H}_{2} \mathrm{O}\right)$ was purchased from Uni Chem, China. For the preparation of phosphate

\footnotetext{
* Author for correspondence, e-mail : aftabshaikh@univdhaka.edu
}

buffer solution (PBS), potassium dihydrogen orthophosphate $\left(\mathrm{KH}_{2} \mathrm{PO}_{4}\right)$ (Merck, Germany), and di-potassium hydrogen phosphate $\left(\mathrm{K}_{2} \mathrm{HPO}_{4}\right)$ (Merck, Germany) were procured and used without further treatment. Ascorbic acid obtained from BDH, UK was used as the ligand.

\section{Equipments}

A three electrode system consists of glassy carbon electrode (GCE) as the working electrode, $\mathrm{Ag} / \mathrm{AgCl}$ (satd. $\mathrm{KCl}$ ) as the reference electrode and platinum wire as the counter electrode were used. Cyclic voltammetric measurement was performed using Computerized Electrochemical System, Model HQ-2040 developed by Advanced Analytics, USA. Solution $\mathrm{pH}$ was measured with a $\mathrm{pH}$ meter of TOA, Model HM-16S.

\section{Methods}

Phosphate buffer solution (PBS) was prepared as follows: $0.1 \mathrm{M} \mathrm{KH}_{2} \mathrm{PO}_{4}$ and $0.1 \mathrm{M} \mathrm{K}_{2} \mathrm{HPO}_{4}$ were prepared separately in two volumetric flasks and then the buffer solutions of $\mathrm{pH}$ $5.30,5.82,6.20,6.39,6.59,6.79$ and 7.20 were prepared by mixing requisite volume of the solution, individually. $\mathrm{CuCl}_{2} .2 \mathrm{H}_{2} \mathrm{O}$ was dissolved in PBS to prepare 1.0, 2.0, 3.0 and $4.0 \mathrm{mM} \mathrm{Cu}$ (II) solutions at different $\mathrm{pH}$ values. Milli-Q deionized water was used throughout the experiments. GCE was polished with fine alumina powder of 0.3 and 0.05 micron on a wet polishing cloth. For doing so a part of the cloth was made wet with deionized water and alumina powder was sprinkled over it. The GCE was then polished on this surface by pressing softly the electrode against the polishing surface for about 10 minutes. A shiny black mirror like electrode surface was then thoroughly washed with deionized water.

First of all, the cell was filled with desired volume of the experimental solution and the Teflon cap was placed on the cell. The purging glass tube together with reference electrode was inserted through the holes. Under computer controlled stirring, experimental solution was deaerated by purging for at least 10 minutes with $99.9977 \%$ pure nitrogen gas. By this way, traces of dissolved oxygen were removed 
from the solution. Solution $\mathrm{pH}$ was varied from 5.30 to 7.20 and the scan rate was varied from 25 to $100 \mathrm{mVs}^{-1}$.

\section{Results and Discussion}

In the present study cyclic voltammetric investigation of $\mathrm{Cu}$ (II) in phosphate buffer solution (PBS) at $\mathrm{pH} 5.30,5.82$, $6.20,6.39,6.59,6.79$ and 7.20 , and its interaction with ascorbic acid of different molar concentrations (1.0, 2.0, 3.0 and $4.0 \mathrm{mM}$ ) at identical condition were carried out at GCE.

\section{Voltammetric response of $\mathrm{Cu}(\mathrm{II})$}

The electrochemical redox behavior of 1.0 to $4.0 \mathrm{mM} \mathrm{Cu}$ (II) solutions in PBS at different $\mathrm{pH}$ (5.30 to 7.20) was investigated at GCE within the potential window of +750 to $-570 \mathrm{mV}$. At more positive or negative potential values only solvent decomposition current was observed.

A typical cyclic voltammogram recorded for $1.0 \mathrm{mM} \mathrm{Cu}(\mathrm{II})$ in PBS with scan rate of $100 \mathrm{mVs}^{-1}$ at $\mathrm{pH} 5.30$ is shown in Fig. 1. In the forward scan a cathodic peak, $i_{p c}$ at about $207.4 \mathrm{mV}$, and in the reverse scan an intense anodic peak, $i_{p a}$ at about $+191.0 \mathrm{mV}$ are observed. In the consecutive redox couple of $\mathrm{Cu}(\mathrm{II}) / \mathrm{Cu}(0)$, the cathodic peak $\left(i_{p c}\right)$ results from the reduction of $\mathrm{Cu}(\mathrm{II})$ to $\mathrm{Cu}(0)$ and the anodic peak $\left(i_{p a}\right)$ is for the oxidation of $\mathrm{Cu}(0)$ to $\mathrm{Cu}(\mathrm{II})$.

The above result suggests that at $\mathrm{pH} 5.30, \mathrm{Cu}$ (II) undergoes one two-electron transfer redox reaction. It agrees well with the previous study ${ }^{26}$. The possible mechanism of the redox reaction for the above cyclic voltammogram is as follow:

$$
\begin{aligned}
& \mathrm{Cu}(\mathrm{II})+2 \mathrm{e}^{-}=\mathrm{Cu}(0) \quad \text { (reduction) } \\
& \mathrm{Cu}(0)=\mathrm{Cu}(\mathrm{II})+2 \mathrm{e}^{-} \quad \text { (oxidation) }
\end{aligned}
$$

\section{Effect of scan rate}

A series of voltammograms of $1.0 \mathrm{mM} \mathrm{Cu}(\mathrm{II})$ at $\mathrm{pH} 5.30$ in PBS at various scan rates such as $25,50,75$ and $100 \mathrm{mVs}^{-1}$ were also recorded as shown in Fig. 2. It is found that both cathodic and anodic peak current linearly increases with the increasing of scan rate. The position of the cathodic peak slightly shifted towards the negative potential and the anodic peak shifted a little towards positive direction with the increase of scan rate. These observations suggest a diffusion controlled redox process in PBS medium.

The peak currents for both cathodic and anodic peak are recorded. Almost a linear variation of peak currents with square root of scan rate is observed suggesting that the process is diffusion controlled. Furthermore a plot of peak current vs scan rate for the cathodic and anodic peaks is also linear. This linear behavior demonstrates a combination of diffusion and surface controlled redox system, where the peak currents for adsorbed and desorbed species are proportional to $v^{1 / 2}$ and $v$, respectively $y^{25,27}$. The cathodic and anodic peak potentials $\left(\mathrm{E}_{\mathrm{p}}\right)$, peak currents $\left(i_{p}\right)$, peak current ratio $\left(i_{p a} / i_{p c}\right)$ and peak potential separation $\left(\Delta \mathrm{E}_{\mathrm{p}}\right)$ are compiled in Table 1.

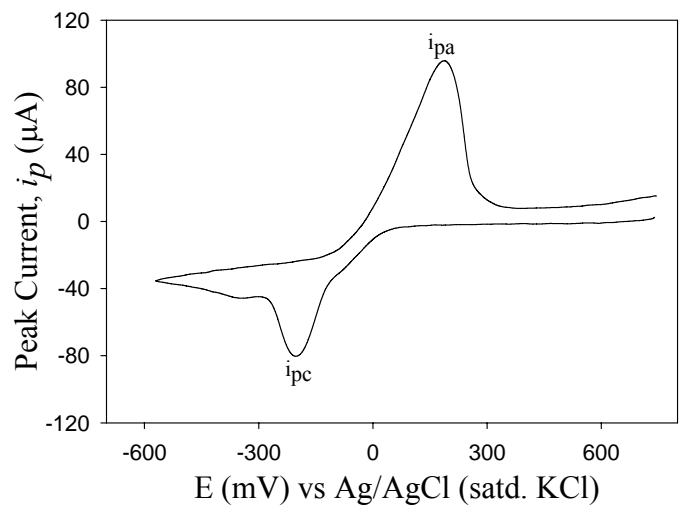

Fig. 1. Cyclic voltammogram response of $1.0 \mathrm{mM} \mathrm{Cu}(\mathrm{II})$ in $\mathrm{PBS}$ at pH 5.30 with scan rate of $100 \mathrm{mVs}^{-1}$ at GCE.

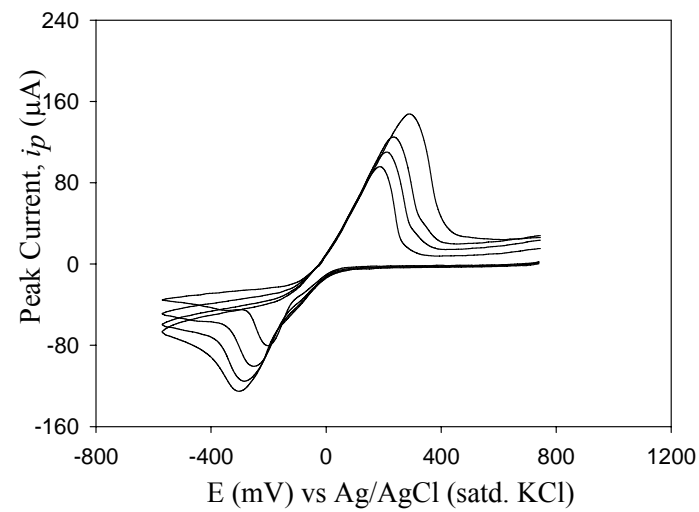

Fig. 2. Cyclic voltammograms of $1.0 \mathrm{mM} \mathrm{Cu}(\mathrm{II})$ in PBS with scan rates of 25, 50, 75 and $100 \mathrm{mVs}^{-1}$ at $\mathrm{pH} 5.30$.

A plot of $\log i$ vs. $\log v$ (Fig. 3) is linear indicating that (i) the process is diffusion controlled ${ }^{28,29}$ and (ii) the peak current is controlled by both charge transfer and mass transport $^{30}$. The ratio of the oxidation peak current to its corresponding reduction counterpart, $\left(i_{p a} / i_{p c}\right)$ is about 1.20 1.09 , and the dependence of peak current ratio with scan rate is shown in Fig. 4. The peak current ratio is greater than unity, which corresponds to a quasi-reversible system ${ }^{27,31}$.

The peak potential separation, $\Delta \mathrm{E}_{\mathrm{p}}$ is in between 397.44 to $592.92 \mathrm{mV}$. It reveals that the peak potential separation increases with the increasing of scan rate. This may be due to the slow electron transfer kinetics or Ohmic potential $\left(\mathrm{iR}_{\mathrm{s}}\right) \mathrm{drop}^{25,32}$.

\section{Effect of concentration}

The cyclic voltammograms of $1.0,2.0,3.0$ and $4.0 \mathrm{mM}$ $\mathrm{Cu}(\mathrm{II})$ in PBS at $100 \mathrm{mVs}^{-1}$ are recorded. It is observed that the voltammograms consists of one cathodic and one anodic 
peak in the studied concentrations of $\mathrm{Cu}$ (II). Both cathodic and anodic peak currents linearly increases with the increasing $\mathrm{Cu}$ (II) concentrations.

The rate of diffusion of $\mathrm{Cu}(\mathrm{II})$ towards the electrode surface thus increases as the concentration of $\mathrm{Cu}$ (II) increases. A gradual increase of peak current with the increase of $\mathrm{Cu}$ (II) concentration was observed. This behavior may be due to the presence of a large amount of electroactive species at

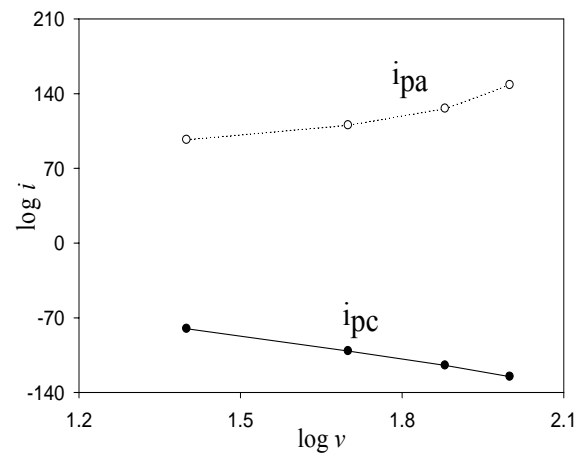

Fig. 3. A plot of $\log i$ vs. $\log v$ for the oltammograms of $1.0 \mathrm{mM} \mathrm{Cu}(\mathrm{II})$ in $\mathrm{PBS}$ at pH 5.30.

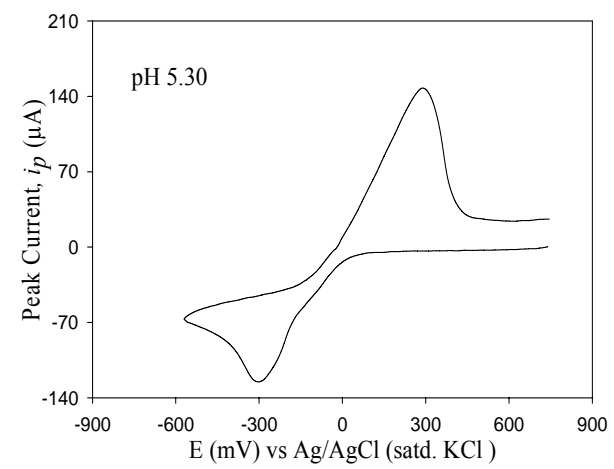

(a)

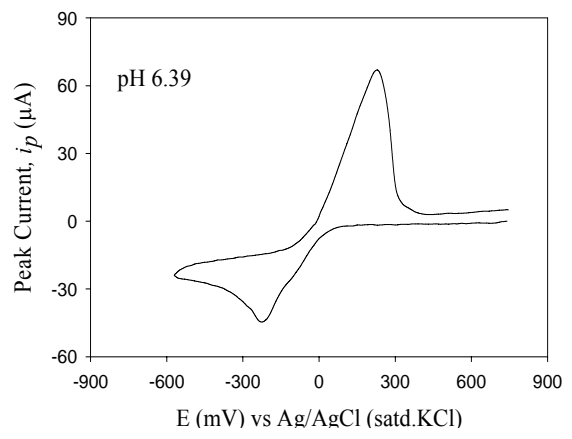

(c) higher concentration ${ }^{33}$. The system also follows a diffusion controlled mechanism ${ }^{27,31}$.

\section{Effect of $\mathrm{pH}$ on the voltammetric response of $\mathrm{Cu}(\mathrm{II})$}

The effect of $\mathrm{pH}$ has also been investigated. The studied pHs are $5.30,5.82,6.20,6.39,6.59,6.79$ and 7.20. The recorded voltammograms for $\mathrm{Cu}(\mathrm{II})$ at different $\mathrm{pH}$ are shown in Fig. 5.

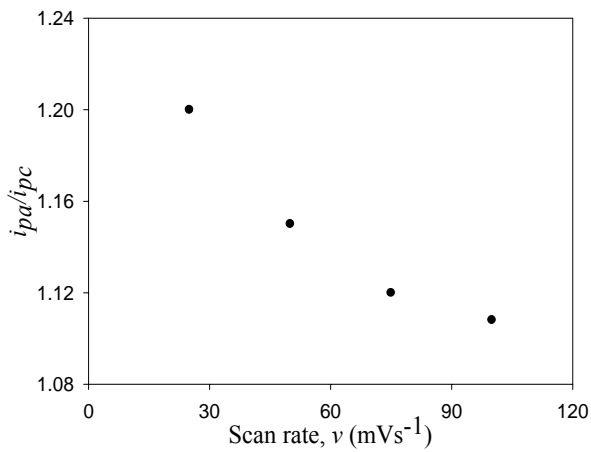

Fig. 4. Dependence of peak current ratio on scan rate of $1.0 \mathrm{mM} \mathrm{Cu}(\mathrm{II})$ in $\mathrm{PBS}$ at $\mathrm{pH}$ 5.30 .

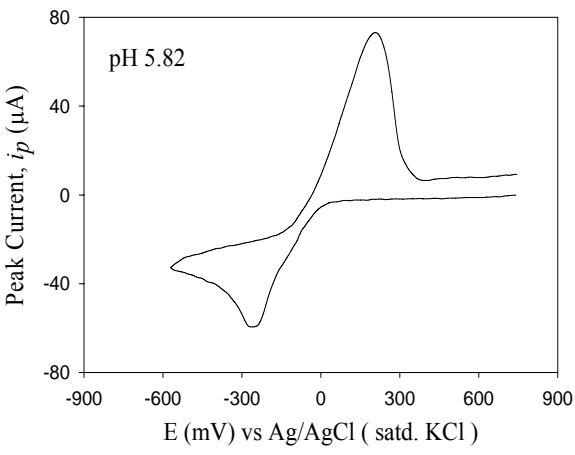

(b)

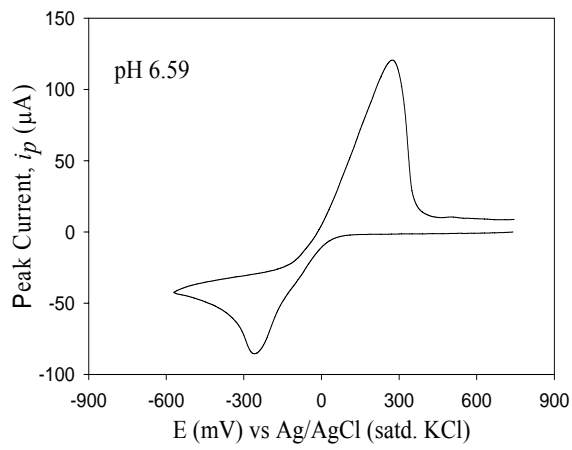

(d)

Fig. 5.Cyclic voltammograms of $1.0 \mathrm{mM} \mathrm{Cu}$ (II) with scan rate of $100 \mathrm{mVs}^{-1}$ at $\mathrm{pH}$ (a) 5.30 , (b) 5.82, (c) 6.39, and (d) 6.59 in PBS at GCE. 
Table 1. Data for the effect of scan rate on peak current and peak potential of $1.0 \mathrm{mM} \mathrm{Cu}(\mathrm{II})$ in PBS at pH 5.30.

\begin{tabular}{cccccccc}
\hline $\begin{array}{l}\text { Scan rate } \\
\left(\mathrm{mVs}^{-1}\right)\end{array}$ & $\begin{array}{l}\text { SQRT of scan } \\
\text { rate }\end{array}$ & \multicolumn{2}{l}{ Peak current $(\mu \mathrm{A})$} & \multicolumn{2}{l}{ Peak potential $(\mathrm{mV})$} & $\Delta \mathrm{E}_{\mathrm{p}}=\mathrm{E}_{\mathrm{pa}}-\mathrm{E}_{\mathrm{pc}}$ & $i_{p a} / i_{p c}$ \\
\hline$v$ & $v^{1 / 2}$ & $(-) i_{p c}$ & $i_{p a}$ & $(-) \mathrm{E}_{\mathrm{pc}}$ & $\mathrm{E}_{\mathrm{pa}}$ & & \\
\hline 25 & 5.00 & 80.20 & 96.80 & 207.44 & 190.00 & 397.44 & 1.20 \\
50 & 7.07 & 101.1 & 110.4 & 252.44 & 208.72 & 461.16 & 1.09 \\
75 & 8.66 & 114.6 & 126.0 & 290.24 & 231.04 & 521.28 & 1.10 \\
100 & 10.00 & 125.0 & 148.2 & 301.4 & 291.52 & 592.92 & 1.19 \\
\hline
\end{tabular}

Table 2. Data obtained from the various voltammograms taken for $\mathrm{Cu}(\mathrm{II})$ in $\mathrm{PBS}$ at different $\mathrm{pH}$.

\begin{tabular}{ccccccc}
\hline Solution $\mathrm{pH}$ & $\mathrm{CPC}, i_{p c} \mu \mathrm{A}(-)$ & $\mathrm{APC}, i_{p a} \mu \mathrm{A}$ & $\mathrm{CPP}, \mathrm{E}_{\mathrm{pc}} \mathrm{mV}(-)$ & $\mathrm{APP}, \mathrm{E}_{\mathrm{pa}} \mathrm{mV}$ & $\Delta \mathrm{Ep}=\mathrm{E}_{\mathrm{pa}}-\mathrm{E}_{\mathrm{pc}}$ & $i_{p a} / i_{p c}$ \\
\hline 5.30 & 125.0 & 148.2 & 301.4 & 291.53 & 592.93 & 1.19 \\
5.82 & 59.52 & 73.20 & 263.0 & 201.52 & 464.52 & 1.23 \\
6.20 & 82.00 & 92.53 & 297.44 & 235.0 & 532.44 & 1.05 \\
6.39 & 44.16 & 67.52 & 226.16 & 223.48 & 449.64 & 1.06 \\
6.59 & 83.51 & 117.73 & 240.0 & 255.0 & 495.0 & 1.42 \\
6.79 & 19.98 & 26.24 & 175.62 & 118.11 & 293.73 & 1.31 \\
7.20 & 112.66 & 171.43 & 186.95 & 274.27 & 461.22 & 1.51 \\
\hline
\end{tabular}

$\mathrm{CPC}=$ Cathodic peak current, $\mathrm{APC}=$ Anodic peak current, $\mathrm{CPP}=$ Cathodic peak potential, $\mathrm{APP}=$ Anodic peak potential

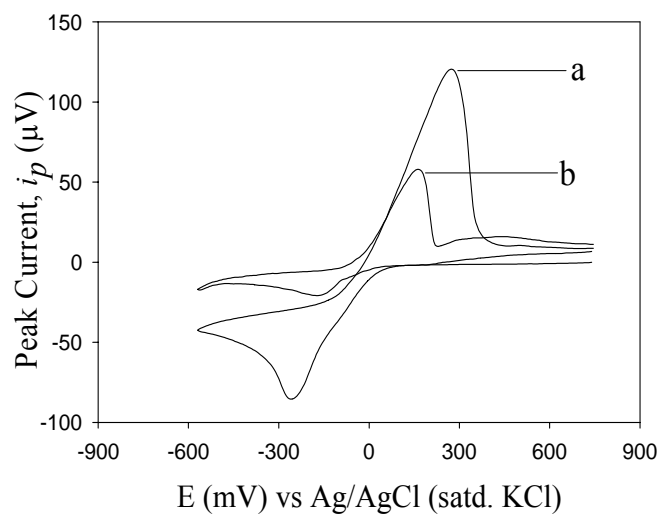

Fig. 6. Cyclic voltammograms of (a) $1.0 \mathrm{mM} \mathrm{Cu}(\mathrm{II})$, and (b) $\mathrm{Cu}$ (II) in presence of ascorbic acid of molar ratio $1: 4$ at $\mathrm{pH} 6.59$ in PBS with scan rate of $100 \mathrm{mVs}^{-1}$ at GCE.

It is observed that at all studied $\mathrm{pH}$ the voltammograms show a cathodic and an intense anodic peak. At lower $\mathrm{pH}$ both cathodic and anodic peak current are high (Table 2). However, with the increase of $\mathrm{pH}$, the cathodic and the anodic peak current gradually decrease. Moreover, the anodic peak and the anodic peak are shifted toward positive and negative values respectively with increasing $\mathrm{pH}$. It implies that the quasi-reversible electrochemical process is shifted towards the irreversible process.

Cyclic voltammetric response of $\mathrm{Cu}(\mathrm{II})$ in presence of ascorbic acid

Cyclic voltammetric response of ascorbic acid in PBS solution at GCE within the potential window of +100 to
$+1000 \mathrm{mV}$ was recorded. It exhibits an intense peak in the anodic region while no peak in the cathodic region within the studied potential window. The interaction of $\mathrm{Cu}$ (II) with ascorbic acid in PBS has been investigated by electrochemical method. The cyclic voltammograms for 1.0 $\mathrm{mM} \mathrm{Cu}(\mathrm{II})$, and $\mathrm{Cu}(\mathrm{II})$ in presence of various molar concentration of ascorbic acid (e.g., $\mathrm{Cu}(\mathrm{II}) /$ ascorbic acid $1: 1,1: 2,1: 3$ and 1:4) at different $\mathrm{pH}(\mathrm{pH} 5.30,5.82,6.20$, $6.39,6.59,6.79$ and 7.20$)$ have been recorded. Voltammograms of $1.0 \mathrm{mM} \mathrm{Cu}(\mathrm{II})$, and $\mathrm{Cu}$ (II) in presence of ascorbic acid of molar ratio 1:4 with scan rate of 100 $\mathrm{mVs}^{-1}$ at $\mathrm{pH} 6.59$ are shown in Fig. 6 .

It reveals that in presence of ascorbic acid the anodic and cathodic peak current are drastically reduced compared to that of solely $\mathrm{Cu}(\mathrm{II})$. Moreover, the peak potentials for both cathodic and anodic peaks are shifted. These results suggest a strong interaction between $\mathrm{Cu}(\mathrm{II})$ and ascorbic acid. The recorded voltammograms for $1.0 \mathrm{mM} \mathrm{Cu}(\mathrm{II})$, and $\mathrm{Cu}$ (II) in presence of various molar concentration of ascorbic acid $(\mathrm{Cu}(\mathrm{II})$ /ascorbic acid 1:1, 1:2, 1:3 and 1:4) at $\mathrm{pH} 5.30,5.82$, 6.39, and 6.59 are shown in Fig. 7.

At all cases, both cathodic and anodic peak heights of $\mathrm{Cu}$ (II) are reduced and the peak potentials are shifted. Nevertheless $\mathrm{Cu}$ (II) undergoes complexation reaction with ascorbic acid at various molar concentration and at different $\mathrm{pH}$.

However, the maximum interaction is occurred for 1:4 molar ratio of $\mathrm{Cu}$ (II) and ascorbic acid at $\mathrm{pH} 5.82$ and 6.59 . This molar ratio might be the suitable condition for the compound formation between $\mathrm{Cu}(\mathrm{II})$ and ascorbic acid. 


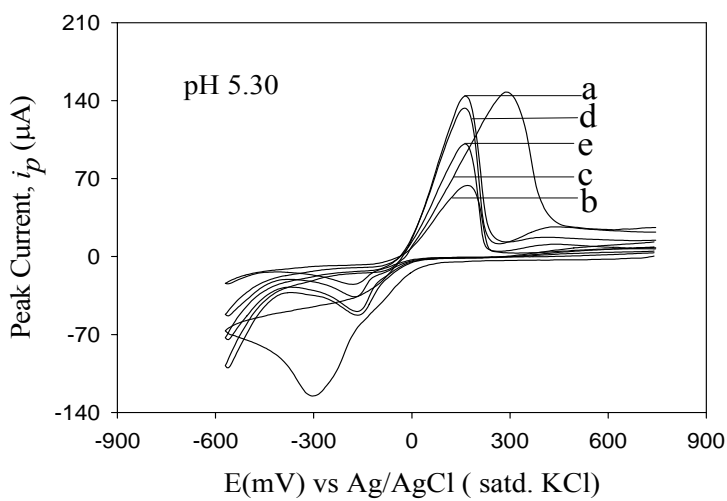

(a)

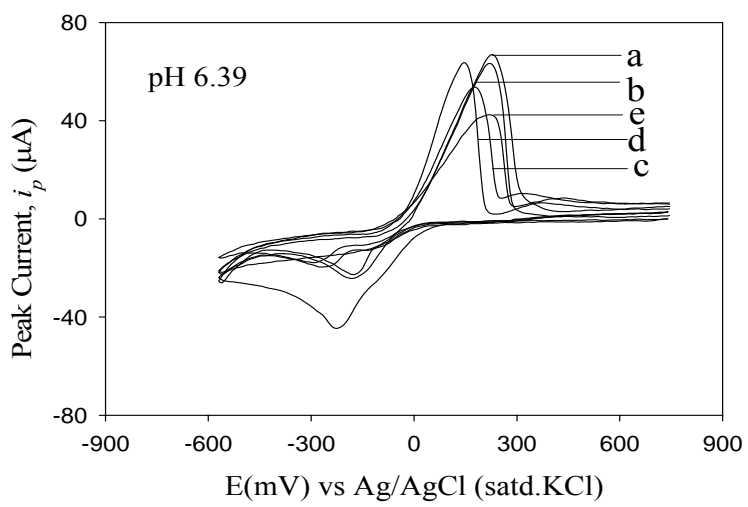

(c)

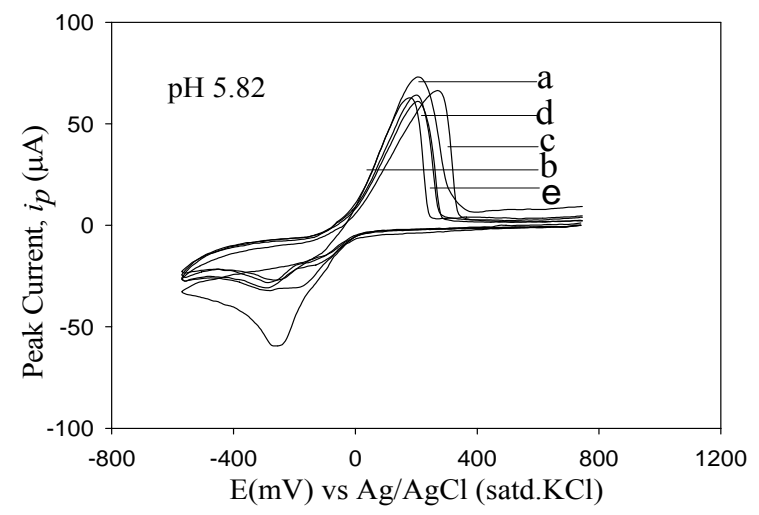

(b)

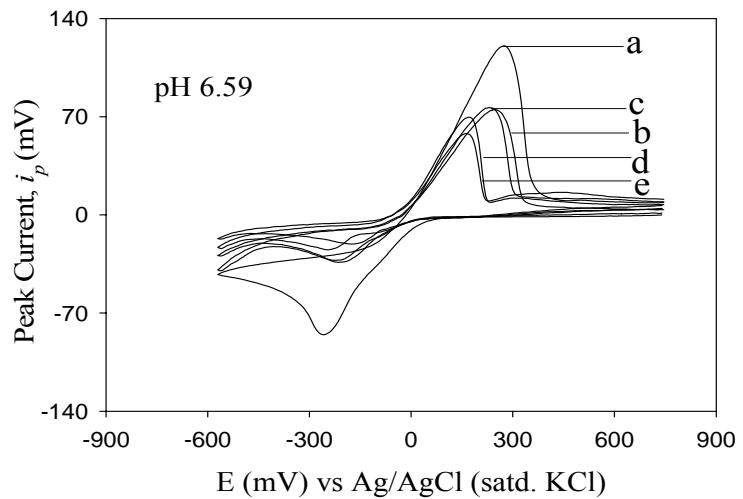

(d)

Fig. 7. Cyclic voltammograms of (a) $1.0 \mathrm{mM} \mathrm{Cu}(\mathrm{II})$, and $\mathrm{Cu}(\mathrm{II})$ in presence of ascorbic acid of molar ratios (b) 1:1, (c) 1:2, (d) $1: 3$ and (e) $1: 4$ at $\mathrm{pH}$ (i) 5.30, (ii) 5.82, (iii) 6.39 and (iv) 6.59 in PBS with scan rate of $100 \mathrm{mVs}^{-1}$ at GCE.

\section{Conclusion}

The electrochemical redox behavior of $\mathrm{Cu}(\mathrm{II})$ in aqueous PBS at different $\mathrm{pH}$ has been studied. A cathodic and an anodic peak is appeared in the voltammograms that reveals $\mathrm{Cu}(\mathrm{II})$ undergoes a one step two-electron transfer electrochemical redox reaction. The linear behavior of peak current against square root of scan rate indicates that the electrochemical process is diffusion controlled. At lower $\mathrm{pH}$ the peak current are very high and gradually decreases with the increase of $\mathrm{pH}$. In presence of ascorbic acid both the cathodic and anodic peak current of $\mathrm{Cu}$ (II) is reduced and the peak positions are shifted compared to those of $\mathrm{Cu}$ (II) alone. These observations suggest that $\mathrm{Cu}$ (II) undergoes a strong interaction with ascorbic acid in the studied condition, and the maximum interaction has been occurred for 1:4 molar ratio of $\mathrm{Cu}$ (II) and ascorbic acid at $\mathrm{pH} 6.59$.

\section{Acknowledgement}

The authors are grateful to the University of Dhaka for financial support.

\section{References}

1. Bernhard, M. and E. Zattera, 1973. Effects of temperature on the toxicity to the aquatic biota of waste discharge, Proc. $2^{\text {nd }}$. Int. Congr. On Marine Waste Disposal, San Rems., 195.

2. White, A., P. Harder and E.L. Smith, 1964. Principles of Biochemistry, $3^{\text {rd }}$ edition, 189.

3. Valpuesta, V. and M.A. Botella, 2004. Biosynthesis of ascorbic acid in plants: new pathways for an old antioxidant, TRENDS in Plant Science, 9, 12.

4. Stone, I., 1972. The natural history of ascorbic acid in the evolution of the mammals and primates and its significance present day man, Orthomolecular Psychiatry, 1, 82-89.

5. Sroka, R. and H. Fischer, 1956. Z. Eletrochem., 60, 109.

6. Kolthof, I.M. and Y. Okinaka, 1959. Cyclic voltammetric studies of $\mathrm{pH}$ dependence of $\mathrm{Cu}(\mathrm{II})$ reduction, J. Am. Chem. Soc., 81. 2296.

7. Mattsson, E. and J.O.M. Bockris, 1959. Mechanism of the dissolution of copper, Trans. Faraday Soc., 55, 1586.

8. Okinaka, Y., S. Toshima and H. Okinaka, 1964. The effect of uncompensated resistance on the potential-step method, Talanta, 11, 203. 
9. Chao, F. and M. Costa, 1968. Mechanism of copper deposition in a sulphate bath containing chlorides, Bull. Soc., Chim. Fr., 10, 4015.

10. Arvinda, C.L., S.M. Mayanna and V.S. Muralidharan, 2000. Electrochemical studied of $\mathrm{pH}$ dependence of $\mathrm{Cu}(\mathrm{II})$, Proc. Indian Acad. Sci., 112, 543.

11. Ambrose, J., R.G. Barradas and D.W. Shoesmith, 1973. Nature and mechanism of anodic film formation on $\mathrm{Cu}$ in alkaline phosphate media, J. Electroanal. Chem., 47, 47.

12. Chander, S. and D.W. Fuerstenau, 1974. Electrochemical studies of copper(II) at glassy carbon electrode, $J$. Electroanal. Chem., 56, 217.

13. Huheey, J.E., E.A. Keiter and R.L. Keiter, 2000. Inorganic Chemistry Principles of Structure and Reactivity, $4^{\text {th }}$ edition, Pearson Education, Inc.

14. Brever, B., F. Gutmann and S. Hacobian, 1951. The polagrographic determination of antimony, Aust. J. Sci. Res., 4 (A), 595.

15. Breyer, B., H.H. Bauer and J.D. Beevers, 1961. Medical chemistry of cardiovascular agents and endocrines, Aust. J. Chem., 14, 479 .

16. Hawkridge, M., Jr. and H.H. Bauer, 1972. Cyclic voltammetric studies of $\mathrm{pH}$ dependence of copper(II) reduction in acidic aqueous nitrate., Anal. Chem., 44, 364.

17. Altermatt, J.A. and S.E. Manahan, 1968. Cyclic voltammetric studies of copper(II) amino acid complexes, Anal. Chem., 40. 655.

18. Brown, O.R. and H.R. Thirsk, 1965. The differential capacitance of polycrystalline copper in aqueous solution, Electrochim Acta, 10, 383.

19. Bixler, J.W. and W.F. Stafford, 1968. Kinetics and mechanism of the reduction of 1.10-phenanthroline, $\mathbf{4 0}, 425$.

20. Stulikova, M. and F. Vydra, 1973. A spectral and polarographic study of the acid-base, J. Electroanal. Chem., 44, 117.
21. Tanaka, N., A. Kitani, A. Yamada and K. Sasaki, 1973. Computer-aided measurements of kinetic parameters of electrode reaction, Electrochim. Acta, 18, 675 .

22. Tindall, G.W. and S.S. Bruckenstein, 1966. Electrochemical studies of copper at glassy carbon electrode, Anal. Chem., 40, 1637.

23. Miller, R.W., 1961. Determination of heterogeneous equilibrium constants by chemical stripping, Ph.D. Thesis, The University of Illinois, Urbana, 3.

24. Shaikh, A.A., S.N. Afzal, M.Q. Ehsan and A.H. Khan, 2005. J. Saudi Chem. Soc., 9(2), 279-286.

25. Shaikh, A.A., M. Begum, A.H. Khan, M.Q. Ehsan and A.H. Khan, 2006. Russ. J. Electrochem, 42(6), 620-625.

26. Shaikh, A.A., J. Firadows, Badrunnessa, S. Serajee, M.S. Rahman and P.K. Bakshi, 2011. Electrochemical studies of the $\mathrm{pH}$ dependence of $\mathrm{Cu}(\mathrm{II})$ reduction in aqueous britton-robinson buffer solution, Int. J. Electrochem. Sci., 6, 2333-2343.

27. Bard, A.J. and L.R. Faulkner, 1980. Electrochemical Methods Fundamentals and Applicatons, JohnWiley and Sons, New York, 228.

28. Mascus, M., F. Parients, Q. Wu, A. Toffanin, J.P. Shapleigh and H.D. Abruna, 1996. Characterization of the gene encoding nitrite reductase, Anal. Chem., 68, 3128.

29. Nicolson, R.S. and I. Shain, 1964. Simulation of the electrochemical behavior of multi-redox system, Anal. Chem, 36, 706.

30. Wang, J., 1948. Analytical Electrochemistry, Wiley-VCH, Inc., New York, 1.

31. Brett, C.M.A., and O. Brett, 1998. Electrochemistry in the presence of convective flow, 145, 1994-1999.

32. Zhang, J., 1972. Electrochemical Methods: Fundamental and Applications, Electro Anal. Chem., 331, 945.

33. Christian, G.D., 2004. Analytical Chemistry, $6^{\text {th }}$ edition, John Wiley and Sons, New York, USA. 